\title{
Sexual behavior of 'Morada Nova' breeding sheep under semi- intensive rearing during the mating season in the brazilian semiarid
}

\author{
Comportamento sexual de reprodutores ovinos Morada Nova \\ durante estação reprodutiva no semiárido em sistema de criação \\ semi-intensiva
}

\author{
Luana de Fátima Damasceno dos Santos ${ }^{1 *}$; Edgard Cavalcanti Pimenta Filho²; \\ Edilson Paes Saraiva²; Dermeval Araújo Furtado; \\ Walter Esfrain Pereira ${ }^{4}$; José Henrique Souza Costa ${ }^{5}$
}

\begin{abstract}
This study aimed to evaluate the sexual behavior of 'Morada Nova' breeding sheep reared in the Brazilian semi-arid during dry and rainy seasons in a semi-intensive system. The behavioral data were gathered from 4 rams and 114 ewes, among which 55 during the rainy season and the other 59 females in the dry season. The behavioral observations were conducted from 6 am to $5 \mathrm{pm}$, during both periods. The observations were carried out continuously and split into 'event' (execution frequency) and 'state' (execution time). During the rainy season, the breeding sheep showed the most efficient sexual behavior, with a shorter reaction time (RT) and less frequent mount attempts (MA), being of $122 \mathrm{sec}$ and 2.97, respectively. However, throughout the dry period, some sexual behaviors such as sniffing the urogenital of females (SUF), penis exposure (EXP), head tossing (HT), and courting of females (FC) became more frequent, mainly in the afternoon, as with the flehmen response (FR). Male courting behavior was more evident in the rainy season during the end of the day, remaining less active during the dry period. Sexual behavior intensity in 'Morada Nova' sheep varies throughout the day, especially in the dry season.

Key words: Sexual courtship. Ethology. Reproduction.
\end{abstract}

\section{Resumo}

Objetivou-se a partir desse trabalho avaliar o comportamento sexual de reprodutores ovinos da raça Morada Nova criados no semiárido brasileiro, durante períodos seco e chuvoso, em criação semiintensiva. Os dados comportamentais foram coletados a partir de 4 carneiros frente a114 fêmeas, 55 fêmeas durante período chuvoso e 59 no período seco. As observações foram realizadas para ambos períodos, das $06 \mathrm{~h} 00$ às $17 \mathrm{~h} 00$, totalizando 11 horas de avaliação diária. Os comportamentos foram obtidos de forma contínua e classificadas como 'evento' (frequência de execução) e 'estado' (tempo de execução). Durante o período chuvoso, os reprodutores mostraram comportamentos sexuais mais eficientes resultando em menor tempo de reação (TR) e menor frequência de tentativas de monta (NST)

${ }^{1}$ Discente, Programa de Pós-Graduação em Engenharia Agrícola, Universidade Federal de Campina Grande, UFCG, Campina Grande, PB, Brasil. E-mail: luana_jppb@yahoo.com.br

2 Profs. Drs., Departamento de Zootecnia, Universidade Federal da Paraíba, UFPB, Centro de Ciências Agrárias, CCA, Areia, PB, Brasil. E-mail: edgardpimenta@gmail.com; edilson@cca.ufpb.br

3 Prof. Dr., Departamento de Engenharia Agrícola, UFCG, Campina Grande, PB, Brasil. E-mail: dermerval@deag.ufcg.edu.br

${ }^{4}$ Prof. Dr., Departamento de Ciências Fundamentais e Sociais, UFPB, CCA, Areia, PB, Brasil. E-mail: walterufpb@yahoo.com.br

${ }^{5}$ Discente, Programa de Pós-Graduação em Engenharia Agrícola, UFCG, Campina Grande, PB, Brasil. E-mail: josehenrique. ufcg@gmail.com

* Author for correspondence 
com 122s e 2,97, respectivamente. Em contrapartida, durante o período seco os comportamentos sexuais: cheirar a região urogenital da fêmea (CRUF), exposição do pênis (EXP), cabecear (CAB) e cortejar fêmeas (COR) foram acentuados, com ênfase durante o turno da tarde aliado ao reflexo de flehmen (RF). Os machos expressaram comportamentos sexuais de cortejo mais evidente no período chuvoso nos turnos finais de avaliação, em contrapartida, permaneceram sem atividade sexual mais frequente durante período seco. A intensidade das condutas comportamentais sexuais dos carneiros Morada Nova varia ao longo do dia, principalmente no período seco.

Palavras-chave: Cortejo sexual. Etologia. Reprodução.

\section{Introduction}

Cariri is an area located in the state of Paraíba - Brazil, within the mesoregion of Borborema, being characterized by high temperatures, low rainfall, and air humidity (BARBOSA et al., 2007). Nevertheless, as stated by Leite et al. (2014), this area still has a great potential for livestock farming, given the existence of a diversity of natural resources. Animal nutritional deficiency may cause losses in herd yields, worsening mainly during the dry season. Thus, well-adapted animal species and a proper management fostering the rearing in such regions are of paramount importance (SEJIAN et al., 2012; WANAPAT et al., 2013).

Sheep belonging to the 'Morada Nova' breed are small and highly adaptable to the semi-arid conditions of the northeastern Brazil (SANTOS et al., 2015). Hence, knowing the behavior of these animals allows the adaptation of proper herd management practices to increase productive and reproductive indexes. The sexual behavior of these animals can provide reliable data about their reproductive capacity, even under adversities influencing these behavioral expressions.

Heat stress has several unfavorable aspects of animal production such as physiological changes (BATISTA et al., 2014), estrus duration, estradiol and progesterone plasma concentrations (SEJIAN et al., 2012), plasma testosterone alterations (MAURYA et al., 2016), feed intake and milk production reductions (NASCIMENTO et al., 2014), besides behavioral changes (SILVA et al., 2016; SANTOS et al., 2015). Therefore, the evaluation of reproductive behavior in the face of adversities can be used as a crucial parameter for selection of sires and dams.
In this sense, the proper choice for dams and sires is a prime factor to increase productivity and profitability in this sector. First, sires should be selected according to their adaptability to climatic conditions, seminal quality, testicular characteristics, and sexual behavior. The latter can be defined as their socio-sexual interaction and is measured by changes in libido and performance of the mating behavior sequence from mate recognition, preparation, and the copula itself.

In general, libido studies are performed in environments other than the rearing sites, such as those intended exclusively for mounting, what might trigger diverse responses in animals. In this bias, studies in semi-intensive and extensive rearing systems allow us to evaluate situations closer to the natural conditions where production animals freely express their behaviors.

In this way, sexual behaviors can be influenced by several factors such as breed, age, breeding seasonality (ROSA et al., 2000), seasonal variation (SANTOS et al., 2015), previous sexual experience, hormonal and social factors (STELLFLUG; LEWIS, 2007), sanity, management and others (COSTA; SILVA, 2007).

Given this background, one may note the need to expand the information on the sexual behavior of 'Morada Nova' male sheep, under a semiintensive rearing system. Moreover, as behavioral patterns are influenced by time of the year, such a study could help in the adoption of efficient management practices for these animals to express their reproductive abilities thoroughly. Therefore, this study focused on evaluating the behavior of sires from 'Morada Nova' breed reared under a 
semi-intensive system in the Brazilian semi-arid, during the dry and rainy seasons (January and June, respectively).

\section{Material and Methods}

The study was carried out in an experimental unit belonging to the Federal University of Paraíba (EESJC/ UFPB). It is located in the city of São João do Cariri, Paraíba state (Brazil), at the geographical coordinates of $07^{\circ} 23$ '2" South latitude and $36^{\circ} 31^{\prime} 5^{\prime}$ "West longitude. The area is at an altitude of $458 \mathrm{~m}$ above sea level and has an average annual rainfall of $450 \mathrm{~mm}$. According to Köppen (1936), the local climate is classified as $B s h$, which stands for predominantly hot, semi-arid, and sub-desert with the tropical tendency.

Behavioral data were gathered from four 'Morada Nova' rams, with a mean age of 5 years, body scoring between 3.5 and 4.0, mean weight of $42.3 \mathrm{~kg} \pm 1.3$ and previous sexual experience. These animals are adapted to the experimental climatic conditions, being born in the Brazilian semiarid region during two periods of the year (dry and rainy seasons). In the rainy season (from June 04 to 20, 2011), 55 'Morada Nova' ewes (24 nulliparous and
31 multiparous) were used for the mating season. Yet during the dry season (from January 03 to 21, 2012), we used 59 'Morada Nova' ewes (32 nulliparous and 27 multiparous), both with a body score ranging from 2.5 to 3.5 . The ratio of males (M) and females (F) in the mating seasons was 1 : 14 in the rainy season, and 1: 15 in the dry period.

Behavioral observations of males were made from 06 am to $5 \mathrm{pm}$, totaling 11 hours of daily evaluation. This period was split into five observation shifts: shift 1 (6:00 am to 7:00 am), shift 2 (7:01 am to 9:00 am), shift 3 (9:01 am to 11:00 am), shift 4 (11:01 am to $3: 00 \mathrm{pm})$, and shift $5(3: 01 \mathrm{pm}$ to 5:00 pm). Both mating seasons totaled 396 hours of evaluation, 209 in the dry period and 187 hours in the rainy season. The observation dates were chosen according to the local climatic conditions, and the term as all females had been bred by season.

Environmental temperature data were recorded per shift, while the relative humidity and accumulated rainfall (rainy season - May, June, and July of 2011; and dry period - October, November, December of 2011, and January 2012) and black globe temperature and humidity index (WBGT) were tabulated per season (Table 1).

Table 1. Average temperature of each shift, relative humidity (RH), black globe temperature and humidity index (WBGT), and accumulated rainfall (AR) for each evaluated season.

\begin{tabular}{ccc}
\hline & \multicolumn{2}{c}{ Seasons } \\
\cline { 2 - 3 } Shifts* & \multicolumn{2}{c}{ Environmental temperature $\left({ }^{\circ} \mathrm{C}\right)$} \\
\cline { 2 - 3 } & Rainy & Dry \\
\cline { 2 - 3 } Shift 1 & 22.5 & 24.4 \\
Shift 2 & 26.3 & 27.4 \\
Shift 3 & 29.9 & 30.4 \\
Shift 4 & 31.4 & 32.7 \\
Shift 5 & 29.6 & 32.6 \\
\hline RH (\%) & 60.2 & 46.1 \\
\hline WBGT & 76.5 & 78.9 \\
\hline AR (mm) & 509.6 & 1.6 \\
\hline
\end{tabular}

${ }^{1}$ Shift 1: 6:00 to 7:00 am; shift 2: 7:01 to 9:00 am; shift 3: 9:01 to 11:00 am; shift 4: 11:01 am to 3:00 pm; and shift 5: 3:01 pm to 5:00 pm. 
The males were previously identified using permanent ink on the side fur (as A, B, C, and D); then they were kept confined in individual pens throughout the experimental period, except that sheep used as a sire for ewes on the day. As shown in Figure 1, each sire remained for three calendar days together with a batch of ewes for behavioral evaluations.

The time of estrus of females was identified at 5:00 pm of each evaluation day, in both seasons. It was performed in smaller pens ( 80 x $20 \mathrm{~m})$, using a partly restrained male. In short, this procedure was carried out only for female estrus detection; once detected, the ewe in potential estrus was identified by a collar and, after 6:00 am, released together with the other females in the behavioral evaluation area. Then, the sire was released, so sexual behavior evaluation could begin.

Confined males were fed diet with sorghum silage and Tifton- 85 hay, besides a concentrated ration based on corn, wheat bran, soybean meal, cotton cake, and mineral supplementation. Food was daily provided as total diet and formulated in accordance with NRC standards (1985). The male used as a sire, as well as females, had access to an area of natural pasture with arboreal and herbaceous strata. At the end of each daily evaluation (at 5:00 pm), after returning to the pen, the ram was supplemented as were the other males. Female diets contained sorghum silage and bermudagrass hay with concentrate formulated according to the standards of NRC (1985).

Figure 1. Diagram of the experimental area for evaluations of sexual behavior of 'Morada Nova' sheep.

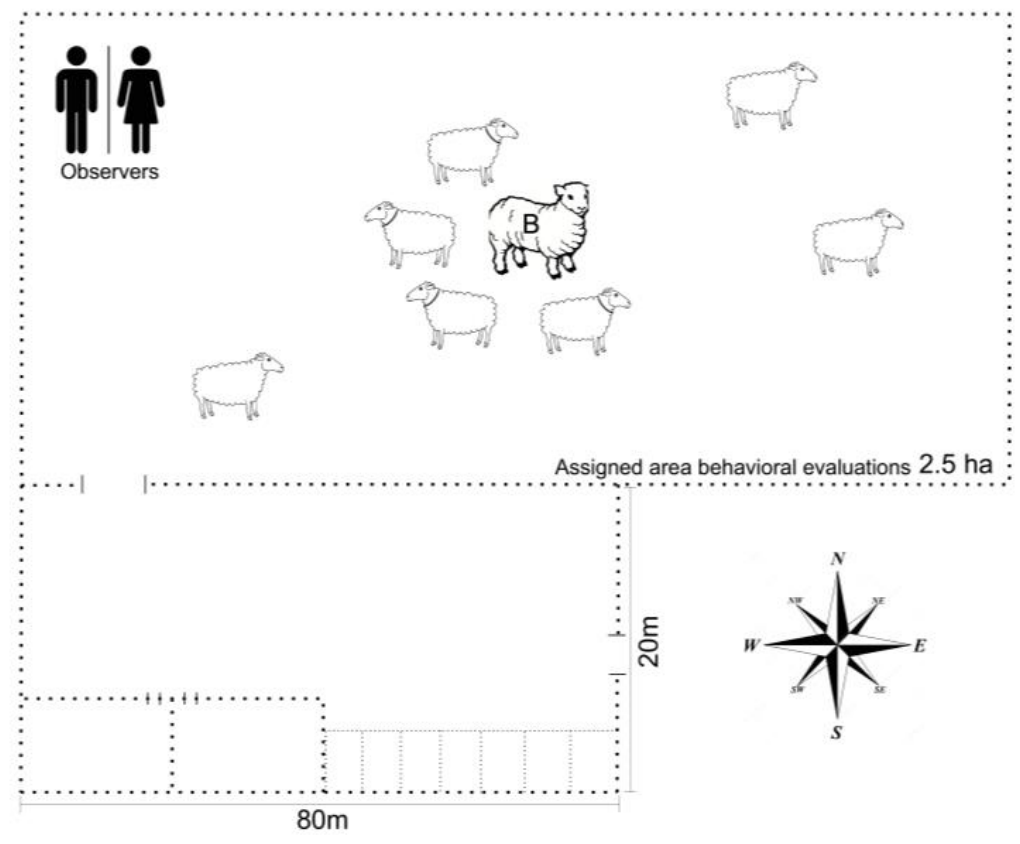

Timing and reaction time (from female in estrus recognition until the mating with the first ejaculation) were recorded in the observations, as well as behavioral actions (male actions in front of a female in estrus until mounting with ejaculation), and the number of leaps (number of times the male leaped towards the female until complete the mating with ejaculation). The behavior was scored by use of an ethogram based on direct behavior, using focal animal sampling.

The behavioral events of animals were classified as 'event' (EV) when it referred to a short duration event, which was evaluated by its frequency, and as 'state' (ST) regarding its duration, being expressed in seconds (Table 2). 
Table 2. Description of behavioral actions expressed by males in event (EV) or state (ST).

\begin{tabular}{ll}
\hline \multicolumn{1}{c}{$\begin{array}{c}\text { Behavior } \\
\text { (Abbreviation) }\end{array}$} & \multicolumn{1}{c}{ Description } \\
\hline RT & $\begin{array}{l}\text { Reaction time (ST) - time elapsed for a male to identify female physiological estrus until } \\
\text { the first mating with ejaculation } \\
\text { Mount attempts }(E V)-\text { number of jumps performed by a ram until it executes full mount } \\
\text { with ejaculation }\end{array}$ \\
MA & $\begin{array}{l}\text { Sniffing the urogenital of females (EV) - preparatory behavior in which a male sniffs the } \\
\text { vulvar region of females }\end{array}$ \\
SUF & Bleats (EV) - vocalizations by rams while approaching females \\
BLT & Flehmen responses (EV) - when males lift the upper lip to sniff female's urogenital region \\
FR & or even the urine \\
TE & Tongue exposure (EV) - ram's sticking out of its tongue when in contact with females \\
EXP & Penis exposure (EV) - when rams show their penises \\
PC & Paw courtship (EV) - kicking using the forelimbs \\
HT & Head tossing (EV) - when rams start horning the females \\
U & Urinate (EV) - Male urination \\
SU & Sniffing urine (EV) - when rams smell female urine while it is urinating or after it \\
CM & Circular motion (EV) - when male and females move in circles simultaneously \\
FC & Female courtship (EV) - male act of approaching or running after females \\
NSA & No apparent sexual activity (EV) - male sheep shows lack of sexual activity towards \\
\hline
\end{tabular}

The data were subjected to a variance analysis by the GLIMMIX procedure. When significant, means were compared by the chi-square test at $5 \%$ probability. We considered 'event' a negative binomial distribution and 'state' a lognormal one. The statistical package used for all analyses was the $\mathrm{SAS}^{\mathrm{TM}}$ (Statistical Analysis System, version 9.3).

\section{Results and Discussion}

WBGT varied during the evaluated periods, with a maximum in the dry season (78.9), being slightly different from the rainy period (76.5). In shifts 4 and 5 , average air temperatures were higher than those of shifts 1, 2, and 3 (Table 1). Such weather changes can affect the sexual behavior of males, since according to Hafez and Hafez (2004); the behavior is reduced in hot climates.

At the same time, while studying the physiological responses of 'Morada Nova' sheep,
Silva Júnior et al. (2014) noted a high physiological capacity to maintain homeothermy at warmer environmental temperatures, displaying a high degree of adaptability to semi-arid regions.

As shown in Table 3, most of the male behaviors towards females in estrus (SUF, EXP, HT, and FC) were significantly different from one season to the other, being more frequent in the dry period. Interestingly, FR presented an inverse behavior to the others.

For Hafez and Hafez (2004), the male sniffing and licking the female perineal region for flehmen responses are patterns for the identification of females in potential estrus. The male noses capture pheromones, which are important chemical markers. This reproductive ability of males in identifying estrus in females is an important feature to be evaluated and considered when choosing a breeding male (KATZ, 2007). 
Table 3. Means of behavioral actions taken by males during the mating in the dry and rainy seasons.

\begin{tabular}{cccc}
\hline \multirow{2}{*}{ Behavioral action $^{1}$} & \multicolumn{3}{c}{ Seasons } \\
\cline { 2 - 4 } & Dry & Rainy & Chi-square \\
\hline SUF & $4.63^{\mathrm{a}}$ & $3.96^{\mathrm{b}}$ & 13.19 \\
FR & $1.39^{\mathrm{b}}$ & $2.92^{\mathrm{a}}$ & 42.22 \\
EXP & $2.78^{\mathrm{a}}$ & $1.75^{\mathrm{b}}$ & 58.89 \\
HT & $0.55^{\mathrm{a}}$ & $0.13^{\mathrm{b}}$ & 17.06 \\
U & 0.02 & 0.01 & 0.01 \\
CM & 0.03 & 0.02 & 0.00 \\
FC & $0.89^{\mathrm{a}}$ & $0.65^{\mathrm{b}}$ & 9.86 \\
\hline
\end{tabular}

Means followed by different letters in a line differ statistically at $5 \%$ probability by the chi-square test for the same parameter; SUF: sniffing urogenital region; FR: flehmen response; EXP: penis exposure; HT: head tossing; U: urinate; CM: circular motion; and FC female courtship.

The most intensive activity of certain male behaviors (SUF, EXP, HT, and FC) throughout the dry period might be due to the climatic conditions and the low pasture availability provided to the females. Under these harsh conditions, estrogen secretion decreases, resulting in a delay in the peak of LH (luteinizing hormone) and delayed follicular development (NAQVI et al., 2004), requiring the male to intensify the female identification and stimulation to make them receptive. Moreover, testosterone, which is responsible for sexual behavior in males (FOURIE et al., 2005), and LH increased when rams are placed together with ewes in estrus (UNGERFELD; SILVA, 2004), raising the behavioral response of males.

According to Santos et al. (2015), the sexual behavior rams is divided into three distinct phases: recognition, preparation, and copulation. The same authors studied 'Morada Nova' male sheep behavior and classified into sniffing the perineal region, courting, and horning as recognition. These behaviors may vary with the period of the year, being more frequent during the dry season.

The flehmen response (FR) is a behavior commonly seen after males sniff the urine or perineal region of females. It is made through the vomeronasal organ allowing the identification of female physiological stage (KATZ, 2007; PACHECO; QUIRINO, 2010). This organ is connected to the central nervous system influencing testosterone plasma levels and sexual behavior to stimulate the male sexually. The mitigation of such behavior during the rainy season may be associated with a higher frequency of female urination, as there is an increase in water intake.

The behavioral actions of SUF, FR, EXP, and FC were significantly different among evaluation shifts $(\mathrm{p}<0.05)$, being more pronounced during the periods of highest temperatures. Differently, the behaviors HT, U, and CM had no difference among shifts along the day $(\mathrm{p}>0.05)$, as displayed in Table 4.

Gill (2008) recorded intensive courtship patterns for females in estrus during the early evaluation times, being then followed by stabilization. However, the same was not observed here, as the behavioral actions intensified in the course of shifts. Conversely, the reduction of these behaviors in the initial shifts is related to a marked male libido and a faster female stimulation for mating. Vitaliano et al. (2012), when studying the sexual behavior of 'Morada Nova' sheep, observed a decrease in some sexual behaviors in the afternoon, what they supposed to be caused by the environmental temperature. 
Table 4. Means of behavioral action frequencies executed by males in each shift of the day.

\begin{tabular}{ccccccc}
\hline \multirow{2}{*}{ Behavioral action $^{2}$} & \multicolumn{5}{c}{ Shifts $^{1}$} & Chi-square \\
\cline { 2 - 6 } & 1 & 2 & 3 & 4 & 5 & 36.29 \\
SUF & $3.08^{\mathrm{b}}$ & $4.01^{\mathrm{ab}}$ & $5.13^{\mathrm{a}}$ & $4.59^{\mathrm{a}}$ & $4.97^{\mathrm{a}}$ & 70.60 \\
FR & $0.77^{\mathrm{c}}$ & $1.53^{\mathrm{bc}}$ & $2.54^{\mathrm{ab}}$ & $2.56^{\mathrm{ab}}$ & $3.00^{\mathrm{a}}$ & 24.21 \\
EXP & $1.82^{\mathrm{b}}$ & $2.40^{\mathrm{ab}}$ & $2.76^{\mathrm{a}}$ & $2.15^{\mathrm{ab}}$ & $2.57^{\mathrm{a}}$ & 6.59 \\
HT & 0.32 & 0.33 & 0.53 & 0.43 & 0.12 & 0.19 \\
U & 0.03 & 0.04 & 0.00 & 0.00 & 0.02 & 0.96 \\
CM & 0.00 & 0.02 & 0.04 & 0.03 & 0.02 & 12.13 \\
FC & $0.60^{\mathrm{c}}$ & $0.65^{\mathrm{c}}$ & $1.03^{\mathrm{a}}$ & $0.92^{\mathrm{a}}$ & $0.72^{\mathrm{b}}$ & \\
\hline
\end{tabular}

Means followed by different letters in a row differ statistically at 5\% probability by the chi-square test; ${ }^{1}$ Shift 1: 6:00 to 7:00 am; shift 2: 7:01 to 9:00 am; shift 3: 9:01 to 11:00 am; shift 4: 11:01 am to 3:00 pm, and shift 5: 3:01 pm to 5:00 pm; ${ }^{2}$ SUF: sniffing urogenital region; FR: flehmen response; EXP: penis exposure; HT: head tossing; U: urinate; CM: circular motion; and FC female courtship.

Since behavior is a socio-sexual interaction, the behavioral actions of females such as grazing and/ or searching for water were intensified between 9:01 and 11:00 am (unpublished data), providing modifications in male behaviors. In this interval, which corresponded to the shift 3, FC was elevated due to the small distance between females and the male while grazing. This behavior aims to test receptivity of females (HAFEZ; HAFEZ, 2004), outlining the sexual interactions able to increase female receptivity, stimulating copulation.

Despite the climatic conditions over shifts, males expressed the behavioral actions of recognition and preparation (SUF, FR, EXP, and FC). Thus, in spite of the challenging conditions, 'Morada Nova' males can be an important genotype to be exploited in semiarid regions, given their high adaptability, aiming to increase sheep productive and reproductive indexes.

Table 5 shows that there was a significant interaction between shifts and seasons $(p<0.05)$ for the following behavioral actions as bleats (BLT), tongue exposure (TE), paw courting (PC), sniffing urine (SU), and no apparent sexual activity (NSA). Over the shifts, recognition and preparatory behaviors of males such as bleats (BLT), tongue exposure (TE), and paw courting (PC) increased during the rainy season. The clustering of animals during the afternoon shifts facilitated the sexual stimulation of males as a function of the gathering of females and secretion of pheromones (VITALIANO et al., 2012). When assessing the sexual behavior of 'Morada Nova' sheep, Santos et al. (2015) elucidated that during reproduction in the rainy season, males express more eminently investigative sex behaviors, manifested at similar frequencies among shifts.

During the dry period, sexual behaviors were reduced, which might have occurred due to natural fatigue, which can be noticed by a reduced number of mount attempts (MA) to perform copulation with ejaculation (Figure 2).

For Banks (1964), out-of-estrus females usually urinate in response to male approach because besides testing the receptivity of females, males increase their libido to perform other activities prior to copula. In addition, as we observed here, the increase in SU, mainly within the initial shifts, was associated with the recognition of female physiological stage in the batch. According to Blissitt et al. (1994), rams can discriminate between the urine odor of estrous ewes and urine odors of ewes from the sixth to first day before estrus and from the fourth to tenth day after estrus. 
Table 5. Means of behavioral action frequencies executed by males in each season ( $\mathrm{R}$ - rainy and $\mathrm{D}$ - dry) and evaluated shift (1, 2, 3, 4, and 5).

\begin{tabular}{|c|c|c|c|c|c|c|c|c|c|c|}
\hline \multirow{4}{*}{ Shifts } & \multicolumn{10}{|c|}{ Behavioral action } \\
\hline & \multicolumn{2}{|c|}{ BLT } & \multicolumn{2}{|c|}{$\mathrm{TE}$} & \multicolumn{2}{|c|}{$\mathrm{PC}$} & \multicolumn{2}{|c|}{ SU } & \multicolumn{2}{|c|}{ NSA } \\
\hline & \multicolumn{10}{|c|}{ Seasons } \\
\hline & $\mathrm{R}$ & $\mathrm{D}$ & $\mathrm{R}$ & $\mathrm{D}$ & $\mathrm{R}$ & $\mathrm{D}$ & $\mathrm{R}$ & $\mathrm{D}$ & $\mathrm{R}$ & $\mathrm{D}$ \\
\hline 1 & $6.75^{\mathrm{Ba}}$ & $5.49^{\mathrm{Ba}}$ & $1.24^{\mathrm{Ba}}$ & $1.96^{\mathrm{Aa}}$ & $4.18^{\mathrm{Ba}}$ & $4.16^{\mathrm{Ba}}$ & $0.05^{\mathrm{ABb}}$ & $0.50^{\mathrm{Aa}}$ & $0.03^{\mathrm{Bb}}$ & $0.36^{\mathrm{BCa}}$ \\
\hline 2 & $8.44^{\mathrm{Ba}}$ & $7.56^{\mathrm{ABa}}$ & $1.86^{\mathrm{Ba}}$ & $2.33^{\mathrm{Aa}}$ & $5.02^{\mathrm{ABa}}$ & $5.70^{\mathrm{ABa}}$ & $0.08^{\mathrm{ABb}}$ & $0.62^{\mathrm{Aa}}$ & $0.28^{\mathrm{ABb}}$ & $0.66^{\mathrm{ABa}}$ \\
\hline 3 & $7.64^{\mathrm{Ba}}$ & $9.41^{\mathrm{Aa}}$ & $2.21^{\mathrm{Ba}}$ & $2.17^{\mathrm{Aa}}$ & $4.23^{\mathrm{Bb}}$ & $7.06^{\mathrm{Aa}}$ & $0.20^{\mathrm{Ab}}$ & $1.04^{\mathrm{Aa}}$ & $0.41^{\mathrm{Ab}}$ & $0.98^{\mathrm{Aa}}$ \\
\hline 4 & $8.82^{\mathrm{Ba}}$ & $9.77^{\mathrm{Aa}}$ & $1.96^{\mathrm{Ba}}$ & $1.68^{\mathrm{Aa}}$ & $4.81^{\mathrm{Bb}}$ & $7.22^{\mathrm{Aa}}$ & $0.00^{\mathrm{Bb}}$ & $1.04^{\mathrm{Aa}}$ & $0.20^{\mathrm{ABb}}$ & $0.55^{\mathrm{ABCa}}$ \\
\hline 5 & $13.47^{\mathrm{Aa}}$ & $9.17^{\mathrm{Ab}}$ & $5.71^{\mathrm{Aa}}$ & $0.64^{\mathrm{Bb}}$ & $7.44^{\mathrm{Aa}}$ & $5.70^{\mathrm{ABa}}$ & $0.04^{\mathrm{ABb}}$ & $0.92^{\mathrm{Aa}}$ & $0.34^{\mathrm{ABa}}$ & $0.18^{\mathrm{Ca}}$ \\
\hline
\end{tabular}

Means followed by different letters, upper-case in columns and lower-case in rows, differ statistically ( $\mathrm{p}<0.05$ ) for the same parameter by the chi-square test; ${ }^{1}$ Shift 1: 6:00 to 7:00 am; shift 2: 7:01 to 9:00 am; shift 3: 9:01 to 11:00 am; shift 4: 11:01 am to 3:00 pm; and shift 5: 3:01 pm to 5:00 pm; bleats (BLT), tongue exposure (TE), paw courtship (PC), sniffing urine (SU), and no apparent sexual activity (NSA).

Figure 2. Number of mount attempts for each evaluated shift with respective mean standard errors.

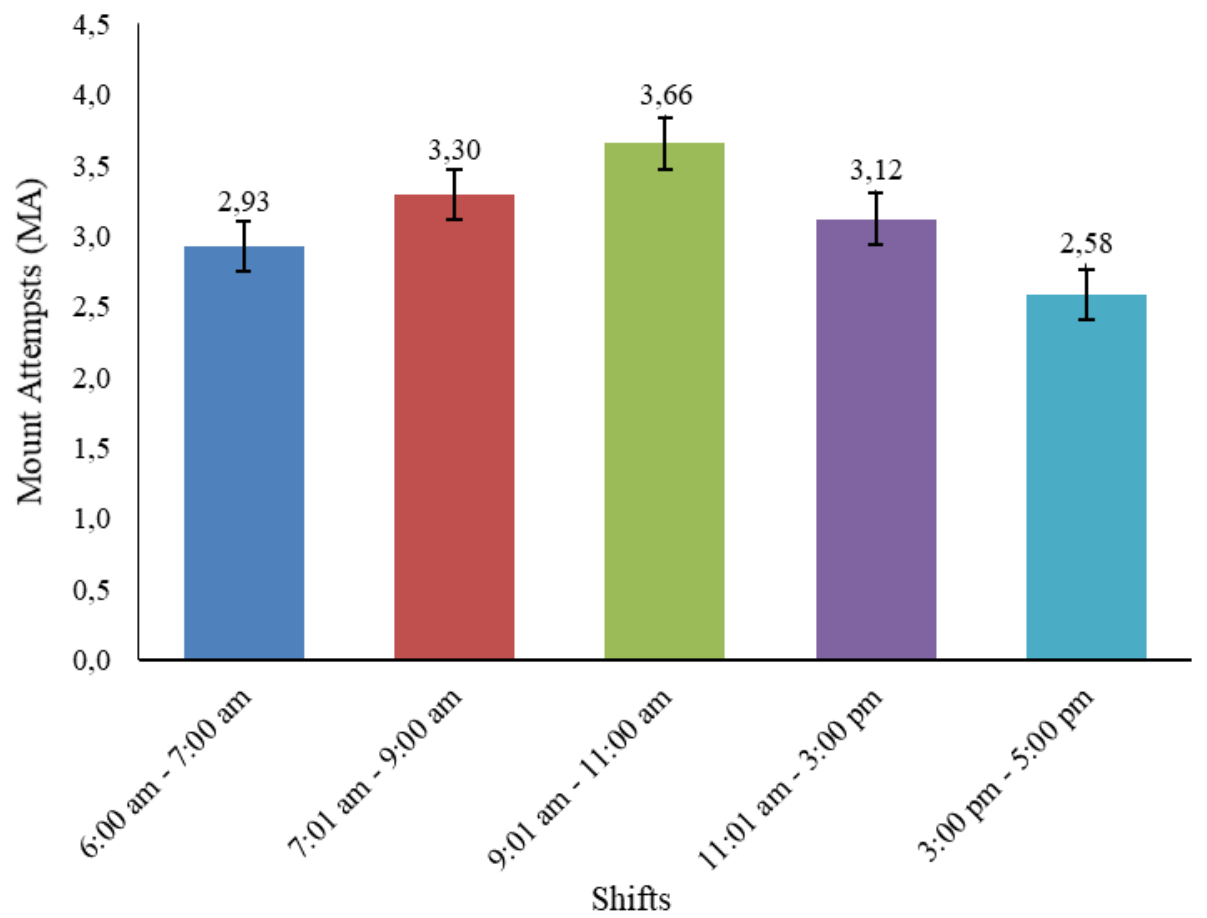

Climatic conditions above the zone of thermoneutrality combined with the animal natural fatigue can develop sexual disinterest on the part of the males. In afternoon shifts, the higher ambient temperatures possibly made animals spend more energy for thermoregulation, so the sexual disinterest and even the pre-ejaculatory interval between mounts enhanced in some shifts (PEPELKO; CLEGG, 1965).
The sexual disinterest exhibited by males (NSA), particularly in the afternoon, is a consequence of natural fatigue arising from sequential exposure of males to mating, and especially due to climatic factors. However, even with these behavioral changes in males from 'Morada Nova' breed, Vitaliano et al. (2012) confirmed the major performance of these animals when compared with other species. 
Pacheco and Quirino (2010) observed such sexual behavior resilience of breeding animals under high-temperature conditions; these authors it as a trait to be indirectly used in the selection of breeds for a tropical climate, as we have seen in 'Morada Nova' sheep. In our study, we could observe that even under adverse climatic conditions (high temperatures), the animals maintained the sexual activities, what make us believe that, for them, species perpetuation is more highly valued than is the thermal comfort itself.

The means of reaction time (RT) and of the number of mount attempts (MA) varied as a function of seasons ( $p<0.05)$, being longer ( 160 seconds) and largest (3.32) during the dry period (Table 6).

Table 6. Means of reaction time - RT (in seconds) and number of mount attempts (MA) as a function of seasons (dry and rainy).

\begin{tabular}{lccc}
\hline \multirow{2}{*}{ Parameter } & \multicolumn{2}{c}{ Seasons } & Chi-square \\
\cline { 2 - 4 } & Dry & Rainy & 3.05 \\
\hline RT $(\mathrm{s})$ & $160^{\mathrm{a}}$ & $122^{\mathrm{b}}$ & 5.41 \\
MA & $3.32^{\mathrm{a}}$ & $2.97^{\mathrm{b}}$ & \\
\hline
\end{tabular}

Means followed by different letters in the row differ statistically for the same parameter at $5 \%$ probability by the chi-square test.

$\mathrm{RT}$ is the elapsed time for a male to identify a female in physiological estrus until the first mount with ejaculation (GARZA et al., 2005). Such a factor is commonly used to prove libido for males, denoting great sexual craving when it is less than 2 minutes (SOUZA et al., 2007; PACHECO; QUIRINO, 2010). Yet, such activity may vary a little, mainly due to the sexual experience of animals, climatic conditions, size of mating paddocks, availability of pasture among others (MOGHADDAM et al., 2012).

Based on our findings, RT mean value during the dry period was $160 \mathrm{~s}$, nearly 2'40", unlike that of the rainy season of $122 \mathrm{~s}$ ( 2 minutes), which is close to standard proposed by Souza et al. (2007). This longer time in the dry period is related to the distance between females and the male within the evaluation area (2.5 ha). Therefore, this outcome was influenced by the size of the evaluation pen as well as by a lower pasture availability in this period. According to Valentim et al. (1997), the shorter the RT expressed by males, the better the reproductive performance.
Regarding the number of MA, we could note that this variable varied with the shifts, reaching the highest value in shift 3 and the lowest average in shift 5 ( $\mathrm{n}=3.66$ vs $\mathrm{n}=2.58$, respectively; $\mathrm{p}<0.05$ ) (Figure 2).

Dry season climatic conditions might have caused subtle reductions in plasma levels of estradiol and $\mathrm{LH}$, concealing estrus and decreasing the sexual reactions of females (NAQVI et al., 2004; SEJIAN et al., 2012). Once estrus manifestation is reduced, males tend to intensify the courtship attempts, i.e. MA, so that female would allow copula. Santos et al. (2015), who studied the sexual behavior of 'Morada Nova' sheep during dry and rainy seasons, obtained similar results; these authors observed variations in MA from 3.18 to 4.10 in the dry period, and from 1.87 to 2.95 in the rainy season.

When considering the natural behavior of females under extensive rearing, Santos et al. (2011) registered a greater grazing time throughout the day, with peaks from 9:00 am to 11:00 am, what resulted in a minor sexual interest. Naturally, this fact contributes to a greater number of sexual 
courtship attempts by males, and hence more MA, as observed in shift 3 (3.66). However, for Santos et al. (2015), repeated MAs may result in an intense reproductive fatigue and reduction of this activity during the day.

The ideal number of MA for breeding male sheep with no fatigue may vary with age, nutrition, sexual experience, among others; therefore, further studies are essential to increase knowledge on such behavior trend (SANTOS et al., 2015). Despite the changes in reproductive behavior with the environmental conditions, 'Morada Nova' sheep were efficient in copulation with ejaculation regardless of shift or season. We may affirm this based on the averages of MA registered in our study, which are within an acceptable range already established by Moghaddam et al. (2012), from 1.2 to 6 jumps per attempt.

\section{Conclusions}

The frequency of sexual behaviors by 'Morada Nova' sheep varies throughout the day, especially during the dry season. Even so, these animals are able to exercise reproductive activity efficiently, given the avidity confirmed by the reaction time and the number of jumps for mounts with ejaculation.

\section{References}

BARBOSA, M. R de V.; LIMA, I. B de.; LIMA, J. R.; CUNHA, J. P da.; AGRA, M de F.; THOMAS, W. W. Vegetação e flora do cariri paraibano, Oecologia brasiliensis. Campina Grande, v. 11, n. 3, p. 313-322, 2007.

BATISTA, N. L.; SOUZA, B. B de.; OLIVEIRA, G. J. C de.; ROBERTO, J. V. B.; ARAÚJO, R. P.; RIBEIRO, T. L. A.; SILVA, R. A. Tolerância ao calor em ovinos de pelames claro e escuro submetidos ao estresse térmico, Journal animal behavior and biometeorology, Patos, v. 2, n. 3, p. 102-108, 2014.

BANKS, E. M. Some aspects of sexual behaviour in domestic sheep, Ovis Áries. Behaviour, Massachusetts, v. 23, n. 3, p. 249-278, 1964.

BLISSITT, M. J.; BLAND, K. P.; COTTRELL, D. F. Detection of oestrous-related odour in ewe urine by rams.
Journal Reproduction and Fertility, Cambridge, v. 101, n. 1, p. 189-191, 1994.

COSTA e SILVA, E. V. Comportamento e eficiência reprodutiva. Revista Brasileira de Reprodução Animal, Belo Horizonte, v. 31, n. 2, p. 177-182, 2007.

FOURIE, P. J.; SCHWALBACH, L. M.; NESER, F. W. C.; GREYLING, J. P. C. Relationship between body measurements and serum testosterone levels of Dorper rams. Small Ruminant Research, v. 56, n. 1, p. 75-80, 2005.

GARZA, R. P.; MARTÍNEZ, L. Z.; GÓMEZ, J. P.; GALVÁN, G. R. Caracterización reproductiva integral del morueco en el ganado lanar de Chiapas. Archives Zootecnia, Cordoba, v. 54, n. 1, p. 557-564, 2005.

GILL, W. Applied sheep behavior. Agricultural extension service. [S.1.: s.n.], 2008. Available at: $\quad<\mathrm{http}: / /$ animalsciense.ag.utk.edu/sheep/pdf/ AppliedSheepBehavior-WWG-2-04.pdf $>$. Accessed at: 6 apr. 2016.

HAFEZ, B.; HAFEZ, E. S. E. Reprodução animal. 7. ed. Barueri: Manole, 2004.

KATZ, L. S. 2007. Sexual behavior of domesticated ruminants. Hormons and Behavior, Atlanta, v. 52, n. 1, p. $56-63,2007$

KÖPPEN, W. Das Geographische system der Klimatologie. Berlim: Borntrager, 1936. 44 p.

LEITE, M. L. de M. V.; SILVA, D. S. da.; ANDRADE, A. P. de.; PEREIRA, W. E.; RAMOS, J. P. de F. Caracterização da produção de palma forrageira no cariri paraibano, Revista Caatinga, Mossoró, v. 27, n. 2, p. 192200, 2014.

MAURYA, V. P.; SEJIAN, V.; KUMAR, D.; NAQVI, S. M. K. Impact of heat stress, nutritional restriction and combined stresses (heat and nutritional) on growth and reproductive performance of Malpura rams under semiarid tropical environment. Journal of Animal Physiology and Animal Nutrition, Bogen, v. 100, n. 5, p. 938-946, 2016.

MOGHADDAM, G.; POURSEIF, M. M.; ASADPOUR, R.; RAFAT, S. A.; JAFARI-JOZANI, R. Relationship between levels of peripheral blood testosterone, sexual behavior, scrotal circumference and seminal parameters in crossbred rams. Acta Scientiae Veterinariae, Porto Alegre, v. 40, n. 3, p. 1-8, 2012.

NAQVI, S. M. K.; MAURYA, V. P.; GULYANI, R.; JOSHI, A.; MITTAL, J. P. The effect of thermal stress on superovulatory response and embryo production in Bharat Merino ewes. Small Ruminant Research, v. 55, n. 1, p. 57-63, 2004. 
NASCIMENTO, C. C. N.; NASCIMENTO, M. R. B de M.; SILVA, N. A. M da. Ocorrência de ondas de calor no triângulo mineiro e alto Paranaíba e seu efeito na produção leiteira e consume alimentar em bovinos. Bioscience Journal, Uberlândia, v. 30, n. 5, p. 14881495, 2014.

NATIONAL RESEACH COUNCIL - NRC. Nutrients requirements of sheep. 6 . ed. Washington, DC, USA, 99 p. 1985.

PACHECO, A.; QUIRINO, C. R. Comportamento Sexual em ovinos. Revista Brasileira de Reprodução Animal, Belo Horizonte, v. 34, n. 2, p. 87-97, 2010.

PEPELKO, W. E.; CLEGG, M. T. Studies of mating behaviour and some factores influencing the sexual response in the male sheep ovis Aries. Animal Behaviour, Massachusetts, v. 13, n. 2, p. 249-258, 1965.

ROSA, H. J. D; JUNIPER, D. T; BRYANT, M. J. The effect of exposure to oestrous ewes on rams sexual behaviour, plasma testosterone concentration and ability to stimulate ovulation in seasonaly anoestrous ewes. Applied Animal Behaviour Science, Mossoró, v. 67, n. 4, p. 293-305, 2000.

SANTOS, M. M dos.; AZEVEDO, M.; COSTA, L. A. B.; SILVA FILHO, F. P.; MODESTO, E. C.; LANA, Â. M. Q. Comportamento de ovinos da raça Santa Inês, de diferentes pelagens, em pastejo. Acta Scientiarum Animal Sciences, Maringá, v. 33, n. 3, p. 287-294, 2011.

SANTOS, S. G. C. G dos.; SARAIVA, E. P.; PIMENTA FILHO, E. C.; SANTOS, L. F. D.; FONSÊCA, V. de F. C.; VERÍSSIMO, T. N. S.; PINHEIRO, A da C. Seasonal and circadian variation of the sexual behavior of Morada Nova rams in tropical environment. Revista Brasileira de Zootecnia, Viçosa, v. 44, n. 1, p. 8-14, 2015.

SEJIAN, V.; MAURYA, V. P.; KUMAR, K.; NAQVI, S. M. K. Effect of multiple stresses (Thermal, Nutritional, and Walking stress) on the reproductive performance of Malpura ewes. Veterinary Medicine International, v. 12, Article ID 471760, p. 1-5, 2012. Available at: <https:// www.hindawi.com/journals/ vmi/2012/471760/.>. Accessed at: 18 jul. 2017.

SILVA JUNIOR, A. M.; DIAS, T. P.; PEREIRA, A. M.; VIANA, G. E. N.; SAMPAIO, K. H.; MARQUES, C. A. T.; COSTA, A. P. R. Efeitos de turno e de raça sobre os parâmetros fisiológicos de ovelhas deslanadas em confinamento no sul do estado do Piauí. Acta Tecnológica, São Luís, v. 9, n. 1, p. 21-25, 2014.

SILVA, M. R.; de SOUZA, B. B.; GUIMARÃES, L. J.; da COSTA, D. F.; ROCHA, E. F.; de OLIVEIRA, S, D. V.; da SILVA, E. M. N. Heat stress and its influence on hormonal physiology of small ruminants. Journal Animal Behavior and Biometerology, Mossoró, v.4, n.2, p. 50-54, 2016.

SOUZA, J. A. T.; CAMPELO, J. E. G.; MACEDO, N. A.; LEAL, T. M.; SOUSA JUNIOR, A.; MEDEIROS, R. M.; MACEDO CHAVES, R. Biometria testicular, caracteristicas seminais, libido e concentração de testosterona em ovinos da raça Santa Inês, criados a campo, na microrregião de Campo Maior, Piauí. Ciência Veterinária dos Trópicos, Recife, v. 10, n. 1, p. 21-28, 2007.

STELLFLUG, J. N; LEWIS, G. S. Effect of early and late exposure to estrual ewes on ram sexual performance classifications. Animal Reproduction Science, Amsterdam, v. 97, n. 3, p. 295-302, 2007.

UNGERFELD, R.; SILVA, L. Ewe effect: endocrine and testicular changes in experienced adult and inexperienced young Corriedale rams used for the ram effect. Animals Reproductive Science, Amsterdam, v. 80, n. 3, p. 251259, 2004.

VALENTIM, R. C.; AZEVEDO, J.; CORREIO, T. M.; TEIXEIRA, A.; AFONSO, M. A. Variação do comportamento sexual de carneiros da raça Churra Galega Braganaça ao longo do outono. Revista de Ciências Agrárias, Recife, v. 20, n. 4, p. 77-88, 1997.

VITALIANO, A. B.; SALLES, M. G. F.; VIANA NETO, A.; RODRIGUES, I. C. S.; ARAÚJO, A. A. Comportamento reprodutivo caprino e ovino utilizando o efeito macho interespécie. Revista Acadêmica Ciências Agrarias e Ambiente, Curitiba, v. 10, n. 3, p. 221-228, 2012.

WANAPAT, M.; KANG, S.; POLYORACH, S. Development of feeding systems and strategies of supplementarion to enhance rumen fermentarion and ruminant production in the tropics. Journal of Animal Science and Biotechnology, Beijing Shi, v. 4, n. 32, p. 2-11, 2013. 
